\title{
Sustainable development of the Polish meat industry after accession to the European Union
}

\author{
mgr Mirosława Tereszczuk ${ }^{1}$, dr inż. Robert Mroczek ${ }^{1}$,
}

\begin{abstract}
The last decade, i.e. 2003-2013, was a period of intensive development of the Polish meat industry, in which Poland's accession to the European Union definitely had its share. The meat industry in Poland has been developing faster that in the EU-15 and Poland was the leader of EU-12. The EU integration had a positive impact on accelerating the production growth in the Polish meat industry, and several years of the process of adjustment to the EU requirements significantly changed the image of the Polish meat companies on the common European market. The Polish meat industry became a significant food producer on the European market (in 2012 fourth place in the EU) and the Polish meat processing plants are recognised as some of the most advanced in the EU. One of the main factors of meat industry development in Poland in the past decade was its very fast development.
\end{abstract}

Key words: sustainable development, meat industry, meat products, export, import

\section{Introduction}

The concept of sustainable development was raised on the international (UN) forum in the 1970s. The most widespread is the definition from the Brundtland Report stating that sustainable development is: "development which meets the needs of the present without compromising the ability of future generations to meet their own needs". Sustainable development is the drive at improvement of the quality of life while maintaining social equity, biodiversity and abundance of natural resources. This definition points to the interrelations between the economic zone of human activity, limited resources of the environment that constitute the natural barrier to the possibilities to meet the needs, and ethical imperative of ensuring social cohesion on a local and global scale [PoniatowskaJaksch 2010]. For the needs of this paper it was assumed that sustainable development of the meat industry should consider the following aspects:

- $\quad$ economic aspect - food industry, including also meat industry, is one of the basic links in the food chain, apart from agricultural producers and trade; as many other sectors of the economy it also contributes to the generation of the Gross Domestic Product and it makes for reduction of trade deficit in Poland since the export of meat and its products exceeds import;

- $\quad$ social aspect - apart from the obvious fact, which is ensuring jobs, meat industry contributes also to the creation of quality changes in respect to agricultural raw materials, e.g. by higher requirements for their producers; it reaches out to the tastes and expectations of the consumers regarding the quality, selection and price of the produced food; it mitigates the growth of the buying-in price of the slaughter animals since the 
changes in the selling prices on its part are usually much lower than those in retail trade. But it is also very important to ensure food safety to the consumer.

- environmental aspect - meat industry has direct and indirect impact on the natural environment because it generates solid, liquid and gas wastes as well as it obtains raw materials for processing (slaughter animals) [Mroczek 2012].

The paper focuses only on some of the above-mentioned issues. The term meat industry means Processing and preserving of meat, excluding poultry meat covered by the $\mathrm{PKD}^{1} 10.11$ and Production of meat and poultry meat products (PKD 10.13). Poultry industry is included in PKD 10.12 as processing and preserving of poultry meat.

\section{Basic information on meat and poultry meat industry in Poland}

Meat industry is the largest section of food industry in Poland. In 2012, the value of sold production of meat industry (including poultry meat - PLN 14 billion) amounted to ca. PLN 55 billion (in current prices) ${ }^{2}$, which accounted for ca. $27.7 \%$ of the value of sold production of food industry ${ }^{3}$. Meat and poultry meat industry enterprises employ ca. 111 thousand persons ${ }^{4}$, which represents ca. $27 \%$ of all those working in the entire food industry (excluding tobacco industry).

In 2004-2012, the number of large enterprises (employing 250 and more workers) in meat and poultry meat industry remained at the same level, i.e. ca. 75 and 20 companies, respectively. Greater changes occurred in the remaining groups of enterprises, especially in small and micro-companies. The number of small companies in meat industry dropped, in the analysed period, by ca. $16 \%$, and micro-companies by $45 \%$, while in poultry meat industry by $33 \%$ and $30 \%$, respectively. In case of medium-sized companies, i.e. employing from 49 to 249 workers, these changes progressed differently, since in the first four years after Poland's integration with the European Union their number increased, and after 2008 it started decreasing (Table 1). This signifies meat sector industrialisation processes taking place in Poland. The largest enterprises are getting increasingly stronger and the small companies are losing with them, which does not, however, mean that they are fighting a losing battle, because they too have a place on the market (niche and local markets). Consumers are increasingly preoccupied with the quality of products and accept a higher price for the so-called traditional and better quality products. Of course, this demand - its scale, results from the level of economic development of a country (enrichment of the society). Small processing establishments can and do offer such products.

In 2004-2012, the share of large companies in red and white meat production increased by ca. 9.8 p.p. (from $43.4 \%$ to $53.2 \%$ ), and the share of medium-sized companies decreased by 2.7 p.p. to $29 \%$. The position of small enterprises has weakened even more, as their share in the production of the sector dropped to $17.8 \%$, i.e. by $7.1 \%$. Small companies, although economically weaker than large companies, are more "flexible" than

\footnotetext{
${ }^{1}$ PKD - Polish Classification of Activities (Polska Klasyfikacja Driałalności)

2 In basic prices, i.e. excluding VAT and excise duty

3 Including manufacture of beverages, but excluding manufacture of tobacco products

${ }^{4}$ I.e. in enterprises employing 10 and more workers as permanent staff
} 
large ones, and products manufactured by small companies are often sold on local and niche markets. Similar trends in the entity structure of enterprises occurred also in employment [Mroczek 2013].

Table 1. Characteristics of meat and poultry meat industry enterprises by size groups of enterprises

\begin{tabular}{|c|c|c|c|c|}
\hline \multirow{2}{*}{\multicolumn{5}{|c|}{$\begin{array}{l}\text { Specification } \\
\text { Meat industry }\end{array}$}} \\
\hline & & & & \\
\hline $\begin{array}{l}\text { Number of enterprises } \\
\text { (companies): }\end{array}$ & $\begin{array}{l}\text { large } \\
\text { medium-sized } \\
\text { small } \\
\quad \text { industrial in total } \\
\text { micro-companies } \\
\quad \text { total }\end{array}$ & $\begin{array}{l}75 \\
293 \\
937 \\
1,305 \\
2,117^{\mathrm{a}} \\
3,422^{\mathrm{a}}\end{array}$ & $\begin{array}{l}77 \\
327 \\
852 \\
1,256 \\
1,637^{\mathrm{a}} \\
2,893^{\mathrm{a}}\end{array}$ & $\begin{array}{l}76 \\
276 \\
786 \\
1,138 \\
1,249 \\
2,387\end{array}$ \\
\hline \multicolumn{5}{|l|}{ Poultry meat industry } \\
\hline $\begin{array}{l}\text { Number of enterprises } \\
\text { (companies): }\end{array}$ & $\begin{array}{l}\text { large } \\
\text { medium-sized } \\
\text { small } \\
\quad \text { industrial in total } \\
\text { micro-companies } \\
\quad \text { total }\end{array}$ & $\begin{array}{l}20 \\
40 \\
143 \\
203 \\
257^{a} \\
460^{a}\end{array}$ & $\begin{array}{l}21 \\
62 \\
105 \\
188 \\
202^{\mathrm{a}} \\
390^{\mathrm{a}}\end{array}$ & $\begin{array}{l}20 \\
55 \\
96 \\
171 \\
229^{\mathrm{a}} \\
400^{\mathrm{a}}\end{array}$ \\
\hline
\end{tabular}

$a-$ own estimations,

Source: Own elaboration on the basis of unpublished data of the Central Statistical Office (CSO) and Eurostat

Figure 1. Entity structure of meat and poultry meat industry enterprises (by percentage of sold production and employment)

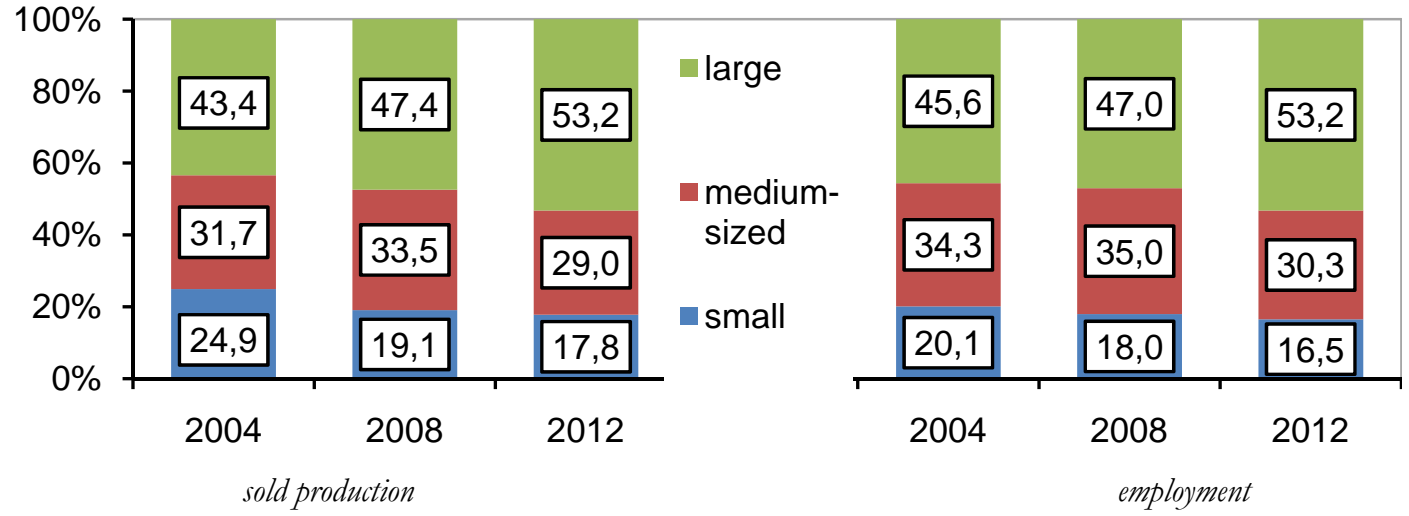

Source: Own elaboration on the basis of unpublished data of the CSO and Eurostat

The meat sector in Poland is under a strong impact of difficult macro-economic conditions, deep crisis in pig farming, as well as high and still growing prices of raw materials and goods. These result in decreasing domestic demand and large import of pigmeat. At the same time, the rapid growth of meat export continues and the links between the entire sector and world market become even stronger, and the poultry meat market, production and processing develop. The trade value of meat companies also increases and a secure financial status maintains, which indicates that they skilfully adapt 
to these difficult conditions (market and macro-economic ones). Producers of live pigs lack such skills mainly due to structural reasons.

The meat market in Poland is affected by growing prices of meat, weakening internal demand, and crisis in pig farming affect (Table 2). On the domestic market, these result in a decrease in meat consumption which in the recent five years dropped by $8.6 \mathrm{~kg}$ per capita, including pigmeat by ca. $7.6 \mathrm{~kg}$ (by 17.4\%), and beef by $2.5 \mathrm{~kg}$, and in foreign trade - in a steep increase in beef import (to 800 thousand tons, i.e. by three times). Poland is a structural pigmeat importer for a few years now, and it has lost its selfsufficiency in the field, the domestic production is by ca. $9 \%$ lower than domestic consumption.

Table 2. Domestic demand and foreign trade in meat products

\begin{tabular}{|c|c|c|c|c|}
\hline Specification & 2007 & 2011 & 2012 & $2013^{\mathrm{a}}$ \\
\hline Meat consumption in kg per capita, including: & 77.6 & 73.4 & 71.0 & 69.0 \\
\hline Pigmeat & 43.6 & 42.5 & 39.2 & 36.0 \\
\hline Beef & 4.0 & 2.1 & 1.6 & 1.5 \\
\hline Poultry meat & 24.0 & 25.0 & 26.1 & 27.0 \\
\hline Meat production in $\mathrm{HCW}^{*}$ in thousand tons, including: & 3,649 & 3,687 & 3,687 & 3,639 \\
\hline - $\quad$ Pigmeat & 2,165 & 1,876 & 1,734 & 1,606 \\
\hline Beef & 369 & 385 & 371 & 373 \\
\hline Poultry meat & 1,115 & 1,426 & 1,582 & 1,660 \\
\hline Export in $\mathrm{HCW}^{*}$ in thousand tons, including: & 837 & 1,313 & 1,494 & 1,593 \\
\hline Pigmeat & 367 & 514 & 595 & 638 \\
\hline Beef & 209 & 309 & 312 & 315 \\
\hline Poultry meat & 261 & 490 & 587 & 643 \\
\hline Import in $\mathrm{HCW}^{*}$ in thousand tons, including: & 369 & 782 & 858 & 928 \\
\hline Pigmeat & 267 & 679 & 747 & 804 \\
\hline Beef & 14 & 20 & 22 & 26 \\
\hline Poultry meat & 88 & 83 & 89 & 98 \\
\hline Value of foreign trade in EUR million: & & & & \\
\hline Export & 1,815 & 3,016 & 3,508 & 3,806 \\
\hline Import & 472 & 1,568 & 1,857 & 2,090 \\
\hline Balance & 1,177 & 1,448 & 1,651 & 1,716 \\
\hline Self-sufficiency index for the sector, including: & 114.7 & 116.8 & 120.8 & 122.4 \\
\hline Pigmeat & 104.8 & 91.9 & 91.9 & 90.6 \\
\hline Beef & 212.1 & 401.0 & 458.0 & 444.0 \\
\hline Poultry meat & 118.4 & 139.9 & 145.9 & 148.9 \\
\hline The share of the export in production in percentage, including: & 22.9 & 35.6 & 40.5 & 43.8 \\
\hline Pigmeat & 17.0 & 27.4 & 34.3 & 39.7 \\
\hline Beef & 56.6 & 80.3 & 84.1 & 84.5 \\
\hline Poultry meat & 23.4 & 34.4 & 37.1 & 38.7 \\
\hline The share of the import in domestic consumption in $\%$, including: & 11.6 & 24.8 & 28.1 & 31.2 \\
\hline Pigmeat & 12.9 & 33.3 & 39.6 & 45.4 \\
\hline Beef & 8.0 & 20.8 & 27.2 & 31.0 \\
\hline Poultry meat & 9.3 & 8.1 & 8.2 & 8.8 \\
\hline
\end{tabular}

${ }^{*} H C W-H o t$ Carcass Weight ${ }^{a}$ initial data; ${ }^{b}$ it is the percentage ratio of production to domestic consumption (production+import+export) Source: Own elaboration on the basis of data from the CSO, Ministry of Agriculture and Rural Development, LAFE-NRI and "Raport miesa" no. 38 of 2010 and no. 46 of 2014 
The role of import of this type of meat is evidenced by the fact that it constitutes $45 \%$ of the domestic consumption of pigmeat and, what is more, $22.7 \%$ of this type of meat production is based on the import of piglets and weaners which in 2013 amounted to as much as 5.13 million animals. At the same time, quick development of meat products export continues. In 2013, their total export and its value was by two times higher than in 2007, while in the last two years its increase exceeded $10 \%$ annually. This refers not only to poultry meat export, but also to pigmeat and beef export. The above resulted in further improvement of the already considerable positive foreign trade balance (to EUR 1.7 billion).

The link between meat production and processing and the European and global market is increasingly stronger. This is evidenced by already high and still growing selfsufficiency indices of the entire meat sector $(122 \%)$ and, in particular beef (over 440\%) and poultry meat (nearly $150 \%$ ). As much as $44 \%$ of the domestic meat production is intended for export, including over $80 \%$ of beef, $40 \%$ of poultry meat and $40 \%$ of pigmeat. If it is also considered that $45 \%$ of the meat consumed in the country is imported, it may be claimed that Polish meat economy is significantly internationalised and open, and that it is increasingly dependent on global phenomena and processes. This is a factor that may increase the pressure to improve efficiency of farming and favour domestic market stabilisation.

\section{Level of adjustment of meat industry companies to the EU requirements}

Poland's accession to the European Union was connected with the implementation of the obligatory systems to ensure food safety and quality management in food industry enterprises, which include: Good Hygiene Practice (GHP), Good Manufacturing Practice (GMP) and Hazard Analysis and Critical Control Points (HACCP). The processes of implementing obligatory quality management systems including HACCP were noted the earliest in large and medium-sized enterprises, and the latest in micro-enterprises. The number of meat sector enterprises that have implemented the obligatory quality management systems increases year-on-year. In 2012, $99 \%$ of meat plants had and used the GHP and GMP systems, while HACCP was implemented in $53 \%$ of plants, $1 \%$ was in the process of its implementation and $46 \%$ of enterprises has not yet started the implementation procedure [Mroczek 2012].

The fastest pace of adjustment of meat and poultry meat plants to the EU requirements was noted in 2004. During these 12 months the number of meat industry plants entitled to trade in the Community market increased by 10 times (from 61 to 638). The poultry meat industry noted a lower, i.e. 4.5-time pace of changes (from 40 to 175 plants). In the next years, the process continued to progress and its dynamics was definitely lower. At present, ca. 1.9 thousand meat ${ }^{5}$ and poultry meat plants can trade their products on the EU market, including ca. 2.7 thousand active companies.

5 These are plants using different systems of integrated production, e.g.: (slaughter+ cutting + processing), (slaughter+cutting, cutting+ production, or only slaughter, cutting or production). 


\section{Position of the meat industry in the food chain}

The ISO 22000 standard defines food chain as a sequence of the stages and operations involved in the production, processing, distribution, storage and handling of food and its ingredients, from primary production to consumption. At each stage there are significant, from the perspective of sustainable development, economic, social and environmental aspects. Responsible food supply chain is the one organised in a manner that allows for harmonious connection of these aspects. In practical terms, this means that all through the process it is sought to minimise the negative impact on the environment and maximise the positive one, not forgetting about the efficiency and profitability of the undertaken actions. The main links of the food chain include: food processors, producers of agricultural crops and sellers (mainly retailers). But this chain is much more complex since these basic links cooperate with other entities, which include:

- $\quad$ feed producers,

- companies providing food and catering services,

- $\quad$ producers of pesticides and fertilisers,

- producers of veterinary drugs,

- $\quad$ transport and storage operators,

- producers of machines and equipment,

- $\quad$ producers of cleaning and disinfection agents,

- producers of packagings,

- $\quad$ service providers (bank, insurance, repair, etc.),

- $\quad$ waste disposal enterprises.

In order for the process to be successful producers, distributors and other entities in the food chain have to cooperate with each other. Each of these groups can implement the principles of sustainable development in a fashion relevant for them.

A significant number of food chain participants results in different types of links between them and sometimes also gives raise to conflicts of interests. In each sector of the economy the largest entities lead the field, as they have the greatest share in the market. The aim is to sell whatever one has produced or bought, and to make money on it. Whoever is stronger or better organised dictates the terms. Different types of slotting fees imposed by large retail chains on food suppliers generate additional costs and thus decrease the profits of processors. In extreme cases this may resemble a situation in which processors become hostages of the large retail chains. As emphasised by Chechelski (2014), it is necessary to introduce changes in the field of cooperation between food suppliers and distributors. At the same time, he points to a difficult situation of small meat processing companies which are not able to compete with the largest meat industry producers in Poland as regards cooperation with retail chains. The number of small grocery stores in Poland decreases (from 160 thousand in 2008 to 110 thousand in 2013 and with a view to 53 thousand in 2020). Nearly 50\% of trade takes place in retail chains (foreign and domestic). What increases is the number of franchise stores, which points to the need for integration and concentration of trade and a new strategy for the processing companies (e.g. production to the local market, production of several ranges of products in long cycles for retail chains, outsourcing of some operations to foreign markets). 


\section{Foreign trade in meat and its products in 2004-2013}

Commercial trade in meat products plays an important part in the sustainability of the meat sector in Poland ${ }^{6}$. Foreign trade in these products forms an important part of the Polish agri-food trade for years. The share of meat products exports in the agrifood exports in 2013 amounted to 19\% and was by 3 p.p. higher than in 2003, while the share of imports amounted to $15 \%$ and was by 11 p.p. higher than in 2003.

Over the 10 years of our membership in the EU structures, the trade in meat products increased by seven and a half time. Revenues from exports of meat and meat products increased by six times to EUR 3.8 billion, including $38 \%$ of pigmeat export, $34 \%$ of poultry meat export and $28 \%$ of beef export. Export volume of meat products (expressed in meat equivalent) increased at that time by over three and a half time (poultry meat export increased the most - by six times to 643 thousand tons). Import of meat products has increased by as much as sixteen times and the greatest increase, i.e. by 23-times was noted in pigmeat import - to EUR 1.8 billion, and 16-times increase in volume - to 804 thousand tons. The balance of foreign trade in meat products in 20042013 increased by almost three and a half time to EUR 1.7 billion (Fig. 2).

Such a significant increase in trade in meat products after the accession resulted from the abolition of customs barriers in trade with the EU Member States and, above all, price competitiveness of our products on foreign markets. Consequently, already in the first years of our membership, the Single European Market became the main outlet and supply market for the Polish meat sector.

Significant changes took place in the structure of exports and imports of meat and its products. In 2004-2013, the share of pigmeat and beef in exports decreased by 6 p.p., respectively, to $40 \%$ and $20 \%$ to the benefit of poultry meat, whose share increased by 12 p.p. to $40 \%$ (Fig. 3). Import is predominated by pigmeat which constitutes nearly $90 \%$ of meat purchased in total. In the structure of import of meat products to Poland the share of poultry meat decreased four times and amounts to ca. $10 \%$.

The main Polish partners in trade in meat and its products are the EU Member States which receive ca. $80 \%$ of our exports. It is, at the same time, the main direction from which we import meat. The outlet markets for meat products starts to diversify. The share of Asian countries (China, Japan, South Korea, and Hong Kong) and the Commonwealth of Independent States (Belarus, Ukraine, Russia) increases, and decreases the share of the EU-15 countries. The Arab states show significant interest in the purchase of beef in Poland, and countries such as: Hong Kong, Benin and China are interested in poultry meat.

${ }^{6}$ Meat products referred to in this paper include: livestock, meat, meat offal, fats and meat preparations from three major meat types, i.e.: pigmeat, beef and poultry, excluding other meat types (i.e.: horsemeat, sheepmeat, game meat, rabbit meat, etc.). 
Figure 2. Foreign trade in meat sector products (thousand tons - meat equivalent)
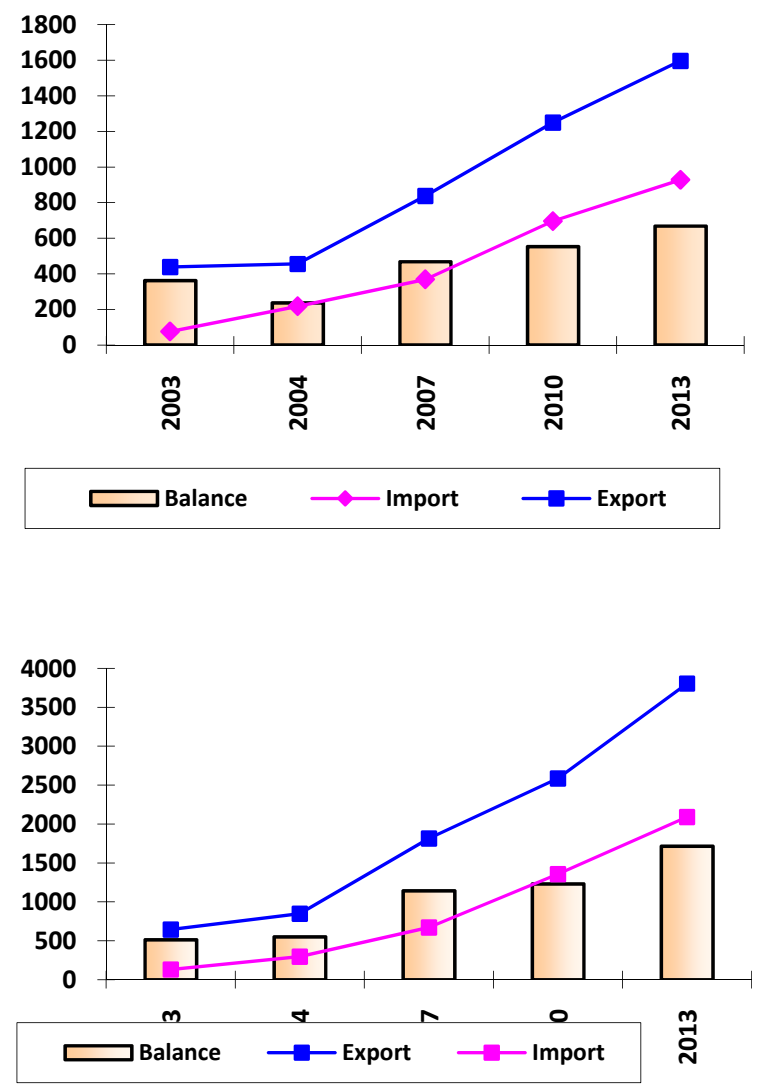

Figure 3. Structure of the range of products in foreign trade in meat products in 2004-2013 (in \%) EXPORT

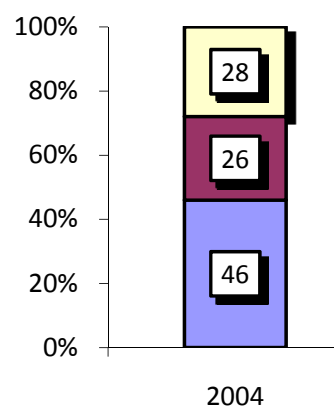

(EUR million)
Source: Own elaboration on the basis of unpublished data of the Customs Administration Analyses Centre (CAAC)
IMPORT

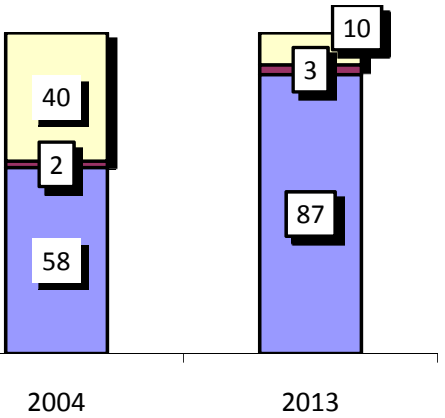

\section{$\square$ pigmeat}

口beef

口poultry

Source: Own elaboration on the basis of unpublished data of the CAAC 
An analysis of export of basic meat products to the value of their sales ${ }^{7}$, carried out for 2004-2012, indicates that in the period of our membership in the European Union the production of meat and meat preparations was marked by strong export orientation. The share of poultry meat export in its sales amounted from $21 \%$ to $37 \%$. The share of red meat in sales was also high and in 2012 it amounted to 34\%. The smallest part of sold production was targeted at export in the group of poultry meat and red meat preparations, but also here an increasing trend was noted. The export orientation of this group of products increased from 8\% in 2004 to 17\% in 2012 (Table 5). The entire sector of meat and meat preparations production is characterised by a slightly lower export orientation than the average for the entire food industry (in 2004-2012 lower by an average of ca. 3 percentage points).

Table 5. The share of export in the value of sold production of meat and meat preparations $(\%)$

\begin{tabular}{|l|l|l|l|l|l|l|l|l|l|}
\hline Specification & 2004 & 2005 & 2006 & 2007 & 2008 & 2009 & 2010 & $2011^{\mathrm{a}}$ & 2012 \\
\hline Red meat & 12.5 & 17.3 & 19.7 & 18.2 & 21.5 & 20.8 & 28.8 & 35.1 & 33.9 \\
\hline Poultry meat red & 21.1 & 25.4 & 36.9 & 28.0 & 25.7 & 24.3 & 29.6 & 27.1 & 30.0 \\
\hline $\begin{array}{l}\text { Preparations from } \\
\text { meat and poultry meat }\end{array}$ & 6.9 & 8.5 & 10.7 & 11.0 & 15.7 & 17.1 & 15.9 & 16.7 \\
\hline $\begin{array}{l}\text { Meat and meat } \\
\text { preparations in total }\end{array}$ & 13.2 & 16.2 & 20.3 & 18.4 & 19.5 & 20.4 & 25.8 & 27.2 & 27.7 \\
\hline Food industry & 17.4 & 20.3 & 22.9 & 21.8 & 22.6 & 25.2 & 28.7 & 29.1 & 30.8 \\
\hline
\end{tabular}

Source: Szczepaniak I. (ed.), Monitoring $i$ ocena konkurencyjności polskich producentón j̇ymności (2). Multiannual Report No. 40, IAFE-NRI, Warsaw 2012.

The study of revealed comparative advantage (RCA $)^{8}$ indicates that in the group of red meat, poultry meat and meat offal this index, over the entire period of our membership, exceeded 2.00. In the group of meat preparations (including fish) it was slightly lower, but after 2010 it also exceeded 2.00. The index of revealed comparative advantage (RCA) for the entire agri-food sector is also high, but definitively lower than in the meat sector (Table 5).

Table 6. The index of revealed comparative advantage (RCA) in the export of meat products and in the total agri-food export

\begin{tabular}{|l|l|l|l|l|l|l|l|l|l|}
\hline Specification & 2004 & 2005 & 2006 & 2007 & 2008 & 2009 & 2010 & 2011 & 2012 \\
\hline $\begin{array}{l}\text { Meat and edible meat } \\
\text { offal }\end{array}$ & 1.62 & 2.18 & 2.46 & 2.38 & 2.40 & 2.23 & 2.62 & 2.74 & 2.88 \\
\hline
\end{tabular}

7 This index expresses the level of involvement of a given country as regards a defined group of products in foreign trade. It is also the measure of export-oriented specialisation of production of a given country. It is assumed that the higher the value of the index, the more export-oriented and competitive on the international market is the production. The lower the index, the producers are less competitive on the international scale.

8 It consists in determining whether the share in exports of a given product (group of products) is higher (or lower) than the share of this product in the global exports. The product is competitive if the RCA is higher than 1.0 . 


\begin{tabular}{|l|l|l|l|l|l|l|l|l|l|}
\hline Meat preparations & 1.58 & 1.57 & 1.63 & 1.78 & 1.88 & 1.98 & 2.21 & 2.13 & 2.23 \\
\hline $\begin{array}{l}\text { Total for agri-food } \\
\text { products }\end{array}$ & 1.19 & 1.42 & 1.44 & 1.39 & 1.31 & 1.34 & 1.41 & 1.36 & 1.46 \\
\hline
\end{tabular}

Source: Own elaboration on the basis of Szczepaniak I. (ed.), Monitoring i ocena konkurencyjnosici polskich producentów symności (4). Multiannual Report No. 74, LAFE-NRI, Warsaw 2013.

Another index to assess competiveness of the meat sector is the trade coverage index (TC-Trade Coverage) ${ }^{9}$. Its values were especially high in beef trade. In 2003-2012, the changes in the TC index were small and amounted to 14.15-18.56 (Table 7).

Table 7. Trade coverage index (TC)

\begin{tabular}{|l|l|l|l|l|l|l|l|l|l|l|}
\hline Specification & 2003 & 2004 & 2005 & 2006 & 2007 & 2008 & 2009 & 2010 & 2011 & 2012 \\
\hline Pigmeat & 2.94 & 1.54 & 1.24 & 1.74 & 1.19 & 0.75 & 0.55 & 0.72 & 0.75 & 0.77 \\
\hline Beef & 18.56 & 17.44 & 15.16 & 19.97 & 12.73 & 16.21 & 21.49 & 15.29 & 14.85 & 14.15 \\
\hline Poultry meat and meat & 5.72 & 3.00 & 4.21 & 4.42 & 4.96 & 6.22 & 5.89 & 6.56 & 6.78 & 7.80 \\
\hline $\begin{array}{l}\text { Meat } \\
\text { preparations in total }\end{array}$ & 4.92 & 2.86 & 2.83 & 3.49 & 2.70 & 1.82 & 1.64 & 1.91 & 1.92 & 1.89 \\
\hline
\end{tabular}

Source: Own elaboration on the basis of unpublished data of the CAAC

The TC index is also high in the poultry meat industry, in which its value increased to 8.0. While in the pigmeat sector the index decreased over three and a half time in 2003-2012 (to 0.77). It means that we are not competitive in the trade in these meat types, which is evidenced by a trade deficit.

\section{The position of the Polish meat industry at the background of the EU countries}

The meat industry is one of the more important industries in the EU food industry. It constitutes $20 \%$ of the value of food industry in the European Union. Poland is the fourth meat and meat offal producer (including poultry meat) in the Community (Fig. 5). The share of our meat industry amounts to $10.6 \%$ of the EU production value. Ahead of us are: Germany with nearly $20 \%$ share, France $(15 \%)$ and Spain $(11 \%)$. The share of EU-15 countries in the EU production of the industry amounts to $80.4 \%$ and the EU-12 - 19.6\%, and Poland is a definite leader among the EU-12 countries that generated 54\% of the sold production value of meat industry of the EU-12.

9 This index defines to what extent the expenses on imports of a given product are covered by revenues from exports of this product. For the needs of this paper, the index was calculated as the ratio of meat products export value to import of the given group of products. If it is higher than one, it means that a given country has relative advantages over its competitors, and if it is lower than one it means that the given country has a weak competitive position on foreign markets. 
Figure 5. The largest producers of meat products in the EU-27 in 2012 (value of trade by purchasing power parity) in EUR billion

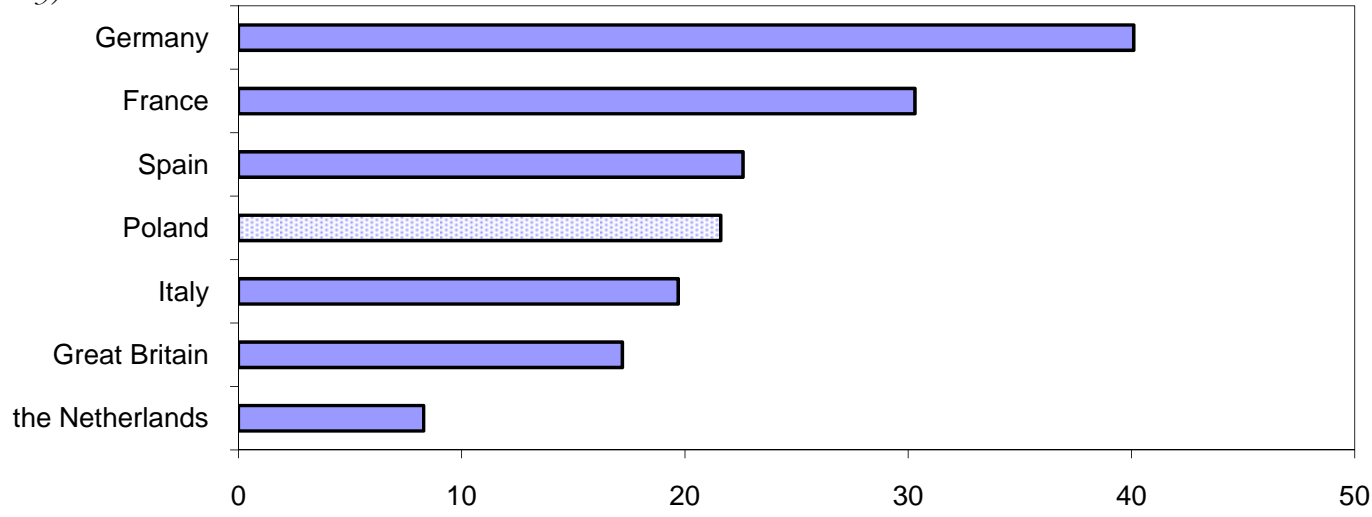

Source: Own elaboration on the basis of Eurostat data

Employment in the EU meat industry amounts to over $20 \%$ of the total number of persons working in the EU meat sector. Labour productivity in the EU meat industry amounts on average to EUR 222 thousand per employed person, including: in the EU15 - EUR 249.5 thousand, and in the EU-12 - EUR 153.2 thousand. The highest labour productivity in the EU meat industry is noted in the Netherlands (EUR 582.4 thousand per employed person), followed by Belgium (EUR 450.0 thousand), and further by Ireland (EUR 338.7 thousand) and Italy (EUR 328.4 thousand). In Germany labour productivity in the meat industry amounts to EUR 203.5 thousand, while in Poland to EUR 181.1 thousand per employed person and it continues to improve.

The average value of trade of a standard meat company in the EU-27 amounts to EUR 5.3 million, while in Poland this index is at the level of EUR 7.8 million and in Germany at the level of EUR 3.6 million. The highest trade value was noted by meat companies operating in Ireland (EUR 32.3 million), Denmark (EUR 25.7 million), Great Britain (EUR 16.7 million) and the Netherlands (EUR 15.5 million).

\section{Conclusions}

Meat industry is the largest section of food industry in Poland. The share of meat industry along with poultry meat industry amounts to ca. $27 \%$ of the value of sold production of the entire food industry (excluding tobacco industry). The structure of meat industry enterprises is fragmented. Half of the sector's production belongs to small and medium-sized meat companies. Higher concentration in noted in poultry meat industry as the share of large companies there amounts to ca. $65 \%$ of the sector's production.

Ten years of membership in the European Union contributed to a rapid development of food industry in Poland, including also meat and poultry meat industry enterprises. Mutual elimination of all trade barriers limiting access to the EU market proved, all in all, beneficial for the Polish food economy. Export of meat and its products in 2004-2013 increased by over three and a half time, to 1.6 million tons and import by as much as 
twelve times to 928 thousand tons (in meat equivalent). Rapidly increasing export of meat and its products would be impossible if the enterprises had failed to adjust to the new EU requirements and standards and, at the same time, they had not been competitive on the Community market and on third country markets. The meat and poultry meat plants were significantly modernised and they have started to introduce innovations on a greater, but still insufficient, scale. At present, the Polish meat plants are among the most advanced in Europe.

But simultaneously high export orientation of the meat sector, its dependence on external sources of raw material supply and development of market links with foreign entities makes the sector very susceptible to changes in global factors such as: violent fluctuations in the economic situation on global markets. These phenomena are strong enough to limit (weaken) the competitiveness of our producers and cause a slowdown in the development of foreign trade in meat products, and, consequently, they pose a significant risk to the sector.

The domestic production and demand for meat has been quite stable for the last few years, but their structure changes. Poultry meat production and export develops quickly, beef is slower in this regard and pigmeat lags far behind. Pigmeat import and processing is significant which results in loss of self-sufficiency of the sector. The crisis is pigmeat production is caused by still fragmented structure of pig farmers that blocks progress in farming efficiency. The growing prices paid to the producers of livestock for slaughter resulted in a decrease in processing profitability and level of investments, and they may restrict the domestic demand and competitiveness of our producers on the global market.

The search for new and attractive outlet markets, and thus their greater diversification is absolutely justified and creates opportunities for further development of the Polish meat and poultry meat industry. The EU market is a saturated market because the production of three basic types of meat (pigmeat, beef and poultry meat) satisfies consumption. The comparative advantages, such as low payment for labour, lower price of land and lower prices of agricultural raw materials, which we had before have started to run out.

Meat industry is thus subject to continuous evaluation, which is manifested in e.g. adjustment of its commercial offer to the needs and preferences of the consumers, search for new "channels" of sales and outlet markets, or meeting specific production norms and standards to ensure food safety.

\section{References}

Chechelski P. 2014: „Przemysł mięsny a sieci handlowe. Uwarunkowania i perspektywy”, Conference in Warsaw 2014.

Mroczek R. (ed.) 2013: Procesy dostosowawcze polskiego przemysłu spożywczego do zmieniającego się otoczenia rynkowego [3], Report No. 75, IAFE-NRI, Warsaw.

Poniatowska-Jaksch, Pakulska T. 2010: „Rozwój zrównoważony - szeroka i wąska interpretacja, stan wiedzy", Warsaw School of Economics, Warsaw.

Szczepaniak I. (ed.) 2013: Monitoring i ocena konkurencyjności polskich producentów żywności (4). Multiannual Report No. 74, IAFE-NRI, Warsaw.

Zegar J. 2012: Współczesne wyzwania rolnictwa, PWE Warsaw. 